\title{
PERJALANAN PARASIT MALARIA DITINJAU DARI ASPEK IMUNOLOGI DAN BIOMOLEKULER
}

\author{
Selfi Renita Rusjdi
}

\begin{abstract}
Abstrak
Infeksi parasit malaria pada tubuh manusia terjadi akibat gigitan nyamuk Anopheles betina yang mengandung sporozoit Plasmodium. Perjalanan parasit ini dari awal infeksi sampai menimbulkan gejala klinis terdiri atas tiga tahap; yaitu tahap pre-eritrositik, tahap intrahepatik dan tahap eritrositik. Pada tahap pre-eritrosit, parasit bergerak aktif di sirkulasi hingga mencapai sel hepar. Tahap intrahepatik dimulai ketika sporozoit berhasil memasuki sel hepar dengan bantuan sel Kupffer melalui pembentukan parasitophorous vacuole. Setelah mengalami perkembangan dan multiplikasi di dalam sel hepar, parasit membentuk skizon yang terdiri dari ribuan merozoit, menempel dan memasuki eritrosit melalui interaksi ligand dengan banyak reseptor. Setiap tahapan ini melibatkan proses molekuler yang komplek termasuk pertahanan tubuh host terhadap invasi Plasmodium.
\end{abstract}

Kata kunci: Parasit malaria, Plasmodium, pre-eritrositik, intrahepatik, eritrositik

\begin{abstract}
Malarial parasites are deposited into human body through the bite of a female Anopheles mosquito which is loaded with sporozoite. The route of these parasites from inoculation until clinical symptoms developed consists of 3 phase: pre-erythrocyte, intrahepatic, erythrocyte. In pre-erythrocyte phase, parasites actively move in blood circulation and enter hepatocyte. Intrahepatic phase starts when sporozoites enter hepatocytes via Kuppfer cells by formation of parasitophorous vacuoles. After invading hepatocytes, sporozoites develop and multiply inside hepatocytes, forming schizonts which are made up thousands of merozoites, attach and invade erythrocyte through ligand interaction with many receptors. Each phase involves complex molecular processes including host immunity to Plasmodium invasion.
\end{abstract}

Keywords: Malaria parasite, Plasmodium, pre-erythrocite, intrahepatic, erythrocyte

Afiliasi Penulis : Bagian Parasitologi Fakultas Kedokteran Universitas Andalas, Korespondensi : Selfi Renita Rusjdi, Bagian Parasitologi Fakultas Kedokteran Universitas Andalas, Jl. Perintis Kemerdekaan No.94 PO BOX 49 Padang 25127, email: selfirenitarusjdi@fk.unand.ac.id, Telp\HP: 08126618120 


\section{PENDAHULUAN}

Malaria adalah penyakit infeksi parasit utama di dunia yang disebabkan oleh protozoa genus Plasmodium. Malaria yang terjadi pada manusia dapat disebabkan oleh 4 spesies plasmodium, yaitu Plasmodium falciparum, Plasmodium vivax, Pasmodium malariae, dan Plasmodium ovale. Plasmodium falciparum merupakan plasmodium yang terpenting karena penyebarannya luas, angka kesakitannya tinggi dan sering menimbulkan malaria berat yang berakhir dengan kematian. ${ }^{1-3}$

Perjalanan parasit malaria dari awal masuk hingga menimbulkan gejala klinis terbagi atas tiga stadium; yaitu stadium preeritrositik, intrahepatik dan eritrositik. Pada masing-masing stadium tersebut terjadi proses molekuler yang kompleks antara parasit dengan host.

\section{METODE}

Penulisan artikel ini berdasarkan studi kepustakaan yang terkait dengan stadium perjalanan parasit malaria dari awal infeksi sampai menimbulkan gejala klinis, yang terdiri atas tiga tahap; yaitu tahap pre-eritrositik, tahap intrahepatik dan tahap eritrositik.

\section{HASIL DAN PEMBAHASAN}

\section{Stadium Pre-eritrositik}

Masuknya parasit malaria ke dalam tubuh manusia didahului oleh gigitan nyamuk Anopheles betina yang mengandung stadium sporozoit. Selain sporozoit, selama proses ini nyamuk juga menginjeksikan saliva yang mengandung antihistamin, vasodilator (takinin) dan anti koagulan (trombin), platelet aggregation inhibitor dan imunomodulator.
Semua zat tersebut berperan untuk mencernakan darah yang dihisap, pertahanan sporozoit dari serangan imunitas hospes dan memfasilitasi proses inokulasi pada kulit manusia. ${ }^{4-6}$

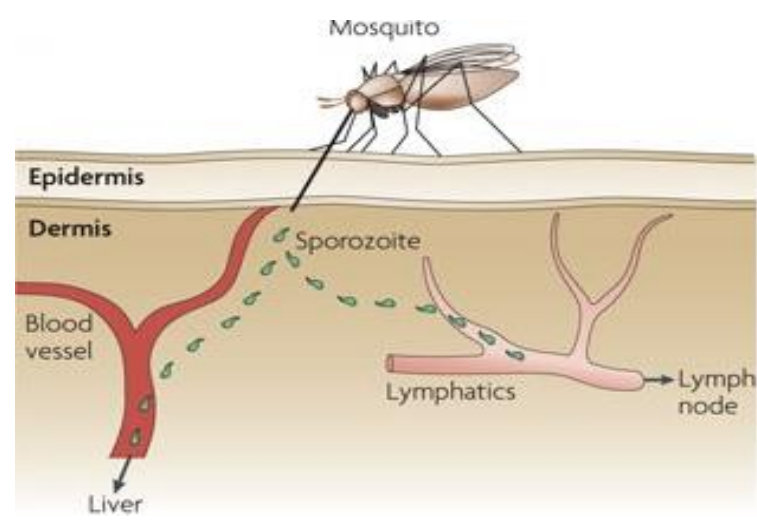

Gambar 1. Injeksi sporozoit melalui gigitan nyamuk (Coombes, 2010)

Beberapa studi telah mendapatkan bahwa, setelah terjadinya inokulasi, sporozoit akan bertahan di kulit dalam periode waktu tertentu. Sporozoit dalam jumlah banyak tersebut akan bergerak aktif untuk mencapai pembuluh darah hingga masuk ke sirkulasi. Kemampuan sporozoit dari Plasmodium untuk bergerak aktif di dermis, menembus endotel vaskuler hingga mencapai sel hepar dibantu oleh protein sporozoit yang dikenal dengan SPECT-1 (Sporozoite microneme protein essential for cell traversal-1), SPECT-2 (Plasmodium perforin - like protein PPLP-1) dan fosfolipase. Protein tersebut mempunyai kemampuan untuk merusak membran plasma sel host. Pada fase awal, sporozoit yang berada di lapisan dermis kulit akan difagosit oleh makrofag di kulit. Makrofag ini bekerja dengan cara fagositosis langsung terhadap plasmodium, mensekresi sitokin untuk mengaktifkan makrofag lainnya dan mensekresi IL-12 untuk merangsang sel Nature Killer un- 
tuk menghasilkan IFN Y. Kemampuan fagositosis dan spesifitas makrofag dapat ditingkatkan oleh sitokin yang dihasilkan sel limfosit $T$ helper yaitu IFN $\mathrm{Y}$ dan IL-2. ${ }^{1}$

Sporozoit yang berhasil lolos dari imunitas lokal di kulit, akan memasuki aliran limfe (30\%) dan aliran darah (70\%) dengan gerakan meluncur (gliding motility) dalam waktu lebih kurang 30 menit. Proses migrasi sporozoit dibantu oleh sporozoite surface phospoholipase. Selama proses migrasi ini sporozoit bisa saja terpapar oleh antibodi terhadap plasmodium surface protein. ${ }^{1,6,7}$

Kekebalan spesifik terhadap stadium sporozoit tidak memberi kekebalan terhadap stadium gametosit, demikian pula sebaliknya. Stadium spesifik ini timbul karena parasit menghasilkan antigen yang berbeda-beda pada masingmasing siklus yang selanjutnya akan merangsang produksi bermacam-macam antibodi spesifik atau mengaktifkan komponen imunitas seluler. Beberapa contoh antigen dari stadium sporozoit tersebut antara lain Sirkumsporozoit protein (Circumsporozoite protein/CSP), Sporozoite Threonin and asparagin rich protein (STARP), Sporozoite and liver stage antigen (SALSA), Plasmodium falciparum sporozoite surface protein-2 (SSP-2/ Trombospondin - related anonymous protein $=$ TRAP). Imunitas pada stadium sporozoit (stadium aseksual eksoeritrosit ekstrahepatal) adalah berupa antibodi yang menghambat masuknya sporozoit ke hepatosit dimana antibodi ini bekerja secara opsonisasi. ${ }^{1}$

Sporozoit yang berada dalam aliran limfe sebagian akan terus menuju limfonodus terdekat. Sporozoit yang terperangkap di limfonodus ini mengaktivasi sel limfosit $T$ untuk membentuk i- munitas spesifik dan sebagian lagi mengalami siklus eksoeritrosit di hepar. Proses aktivasi limfosit di dalam limfonodus ini dibantu oleh sel dendritik dan makrofag yang juga berperan sebagai Antigen Presenting Cell. Sel limfosit yang teraktivasi akan mengalami resirkulasi dan masuk ke hepar. 1,7,8

Sporozoit yang masuk ke aliran darah akan sampai di hepar dalam beberapa jam dengan gerakan stick and slip motility. Gerakan ini terjadi akibat aktifitas aktin miosin dan interaksi thrombospondin - related anonymous protein (TRAP) yang merupakan Circumsporozoit protein (CSP) dengan heparan sulphate proteoglycans (HSPGs) pada mikrovili hepatosit. Heparan sulphate proteoglycans (HSPGs) merupakan reseptor plasmodium pada sinusoid hepar. Selain di hepar, HSPG juga terdapat pada hampir seluruh jaringan tunbuh, tetapi kandungan sulfat pada hepar lebih tinggi dibandingkan dengan jaringan tubuh yang lain. ${ }^{6}$

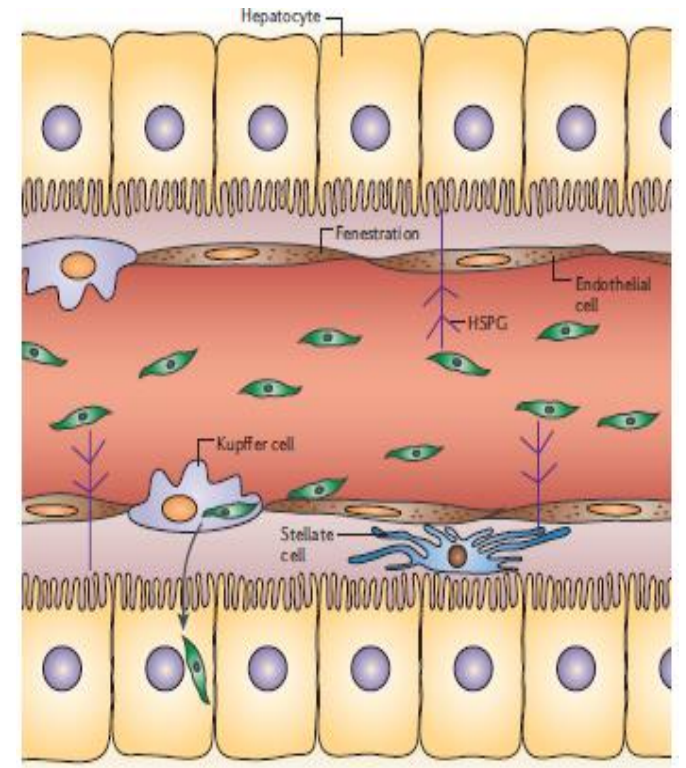

Gambar 2. Interaksi Circumsporozoit protein (CSP) dengan heparin-sulphate proteoglycans (HSPGs) untuk menginvasi hepatosit (Prudencio, 2006) 
Protein sporozoit seperti CSP dan TRAP, tidak hanya dapat mengenal proteoglikan permukaan spesifik yang terdapat pada permukaan sel hepar tetapi juga proteoglikan yang terdapat pada sel Kupfer dan sel stelata. Sel Kupfer merupakan sel makrofag di hepar yang terletak antara sel endotel sinusoid. Sel stelata adalah sel perisinusoid yang sangat bercabang dan berperan dalam pembentukan matriks ekstraseluler dan proses inflamasi di hepar. Sel stelata ini mempunyai kemampuan membentuk sulfat proteoglikan delapan kali lebih dan heparan sulfat dua kali lebih banyak banyak dibandingkan dengan sel hepar. Matriks proteoglikan sel stelata ini mengalami fenestrasi melalui sel endotel dan menonjol ke ruang sinusoid hepar. Keadaan ini memungkinkan sporozoit tertahan di sinusoid hepar. ${ }^{6}$

\section{Stadium Intrahepatik}

Setelah sporozoit tertahan di daerah sinusoid hepar, sporozoit akan terus berusaha mencapai dan menginvasi sel hepar. Proses invasi sporozit ini hanya bisa melalui sel Kupfer dikarenakan sel endotel sinusoid mempunyai diameter fenestrasi nyang sangat kecil sehingga tidak memungkinkan untuk dilewati oleh sporozoit. Masuknya sopozoit ke dalam sel Kupfer terjadi memalui pembentukan parasitophorous vacuole. Pada proses invasi ini tidak terjadi fagositosis karena vakuol yang terbentuk tidak mengalami fusi dengan lisosom. Kecepatan invasi sel Kupfer oleh sporozoit lebih lambat dibandingkan dengan kecepatan sprorozoit menembus sel yang dilakukan dengan cara merusak membran sel. ${ }^{6}$

Sporozoit yang berhasil masuk melalui sel Kupfer akan melewati ruang perisinusoid (space of Disse) dan bermigrasi dari satu hepatosit ke hepatosit lain dan berakhir pada hepatosit terakhir yang membentuk parasitophorous vacuole. Kerusakan membran hepatosit akibat migrasi sporozoit ini disebabkan oleh aktifitas enzim lipase, protease dan poreforming protein. Kerusakan membran hepatosit bersifat reversibel dan dapat utuh kembali secara spontan. Kerusakan yang terjadi akan menginduksi sekresi hepatocyte growth factor (HGF) yang merupakan suatu protein yang dapat meningkatkan kerentanan untuk terinfeksi plasmodium di kemudian hari. Mekanisme terdapatnya kecendrungan sporozoit untuk memilih atau menempati suatu hepatosit di antara banyak hepatosit lainnya masih belum diketahui. ${ }^{6}$

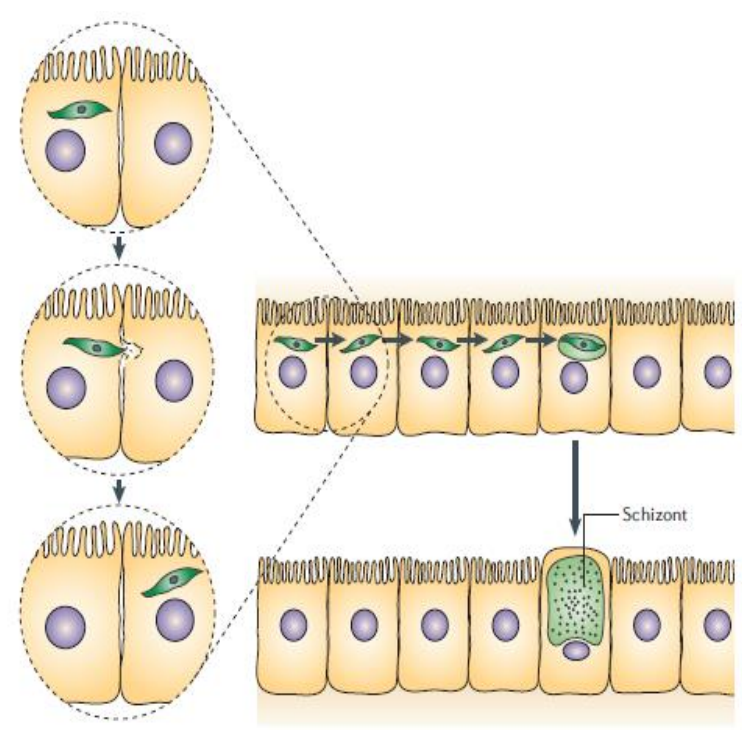

Gambar 3. Migrasi, mturasi dan replikasi sporozoit di dalam hepatosit. ${ }^{6}$

Setelah sampai pada hepatosit yang dituju, sporozoit bermutiplikasi di dalam disebut parasitoporous vacuole atau biasa juga disebut merosom. Membran merosom dibentuk dari membran sel hepar (host derived membrane) yang tidak lagi mengandung protein hepatosit 
sehingga parasit dari terhindar aktifitas fagosit sel Kupfer. Proses multiplikasi ini difasilitasi oleh circumsporozoit protein. Merozoit ini nantinya akan lepas dari merosom di kapiler paru dan kemudian mengikuti aliran darah. Pada P.vivax dan $P$.ovale, proses ini tidak berlangsung segera akan tetapi terlebih dahulu membentuk hipnozoit yang dikenal sebagai bentuk laten atau dorman. ${ }^{9,11,12}$

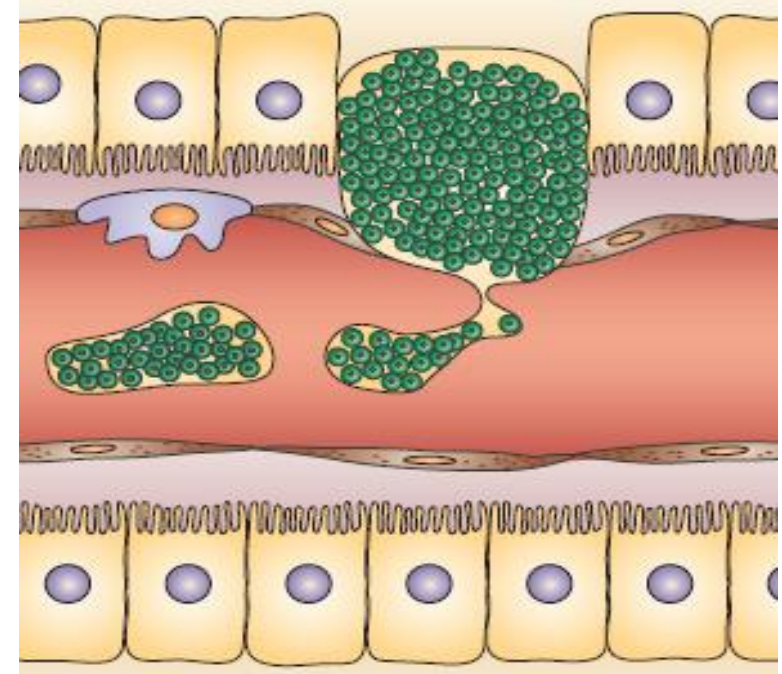

Gambar 4. Merozoit dalam merosom keluar dari hepatosit menuju sirkulasi ${ }^{6}$

\section{Stadium eritrositik}

Setelah mengalami multiplikasi di dalam merosom, merozoit akan keluar dari hepatosit menuju sirkulasi. Saat merozoit bebas dari merosom di kapiler paru, dalam waktu 20 detik merozoit langsung menempel dan memasuki eritrosit melalui interaksi ligand multi reseptor. Keberadaan merozoit yang sangat singkat di dalam sirkulasi ini meminimalisir kontak merozoit dengan sistem imun hospes. Proses merozoit menginvasi eritrosit ini terjadi melalui 4 tahap, yaitu terbentuknya ikatan antara merozoit dengan reseptornya di permukaan eritrosit, reorientasi apikal dan peru- bahan bentuk eritrosit, pembentukan junction dan masuknya merozoit ke dalam eritrosit. ${ }^{13-15}$

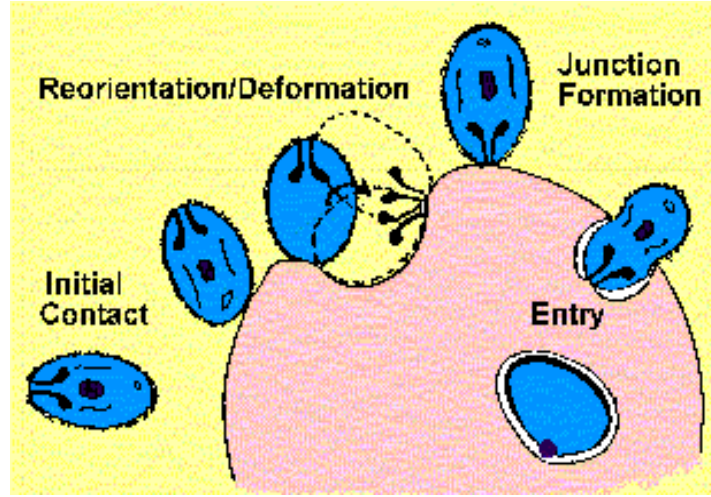

Gambar 5. Proses invasi merozoit ke dalam eritrosit $^{15}$

\section{a. Ikatan merozoit dengan reseptor di permukaan eritrosit}

Kontak awal (initial contact) merozoit dengan eritrosit dapat terjadi di setiap bagian permukaan merozit. Terbentuknya ikatan merozoit dengan eritrosit terjadi akibat adanya interaksi antara protein pada permukaan merozoit (Merozoit Surface Protein / MSP) dengan protein reseptor yang terdapat di permukaan eritrosit. ${ }^{15,16}$

Protein permukaan merozoit $P$.falciparum yang berperan membentuk ikatan merozoit - eritrosit adalah MSP-1 dan MSP-2. Kedua molekul ini dihubungkan dengan membran oleh suatu komplek glikolipid yang dikenal sebagai GPI anchor (glycosylphosphatidylinositol anchor). Ikatan merozoit-eritrosit ini terjadi karena adanya peranan Merozoit Surface Protein bersama-sama dengan erythrocyte-binding protein (EBA-165). Pada P.vivax, protein permukaan yang terlibat adalah PvMSP-1, reticulocytebinding proteins (RBP-1 and RBP-2) dan Duffy adhesion protein (DAP-1). ${ }^{15}$

Reseptor merozoit di permukaan eritrosit ini berbeda-beda tergantung 
spesies merozoit yang menginvasi. Reseptor eritrosit pada P.falciparum adalah sialic acid, glycophorins dan band 3 dan merozoit dapat menginvasi semua umur eritrosit. Pada P.vivax, reseptor eritrositnya adalah antigen duffy dan hanya menginvasi eritrosit muda (retikulosit). ${ }^{15}$

\section{b. Reorientasi apikal dan perubahan bentuk eritrosit}

Setelah terbentuk ikatan antara merozoit dengan reseptor di permukaan eritrosit, merozoit akan melakukan reorientasi apikal yaitu memutar bagian tubuhnya sedemikian rupa sehingga bagian apek berhadapan langsung dengan permukaan eritrosit. Proses reorientasi ini terjadi karena adanya Apical membrane antigen-1 (AMA-1). Pada tahap ini, organel berupa micronemes, rhoptries, dan dense granules terletak pada bagian apeks dan masingmasing organel ini akan mensekresikan zat yang dikandungnya ke dalam membran eritrosit. Micronemes merupakan organel yang paling awal mengeluarkan sekret, kemudian diikuti oleh rhoptries dan dense granules. Sekresi micronemes ini ditandai dengan peningkatan kadar kalsium dalam sitoplasma. Rhoptries mensekresikan segera setelah micronemes dan zat yang disekresikan berperan dalam pembentukan parasitephorous vacuole. Sekresi dense granules terjadi paling akhir dan berperan dalam perubahan bentuk eritrosit. ${ }^{15}$

\section{c. Pembentukan junction}

Pembentukan junction terjadi karena adanya peranan protein yang disekresikan oleh micronema dan diikuti oleh pelepasan protein dari leher rhoptry (neck of rhoptry). Junction merupakan ikatan merozoit - eritrosit yang kuat yang diperantarai oleh ikatan reseptor pada permukaan eritrosit dengan ligand yang terdapat pada permukaan merozoit. Protein micronema yang membentuk ligand tersebut antara lain EBA-175 atau erythrocyte binding antigen-175 pada $P$. falciparum, DBP - Duffy-binding protein untuk $P$. vivax and $P$. knowlesi dan SSP2 - Plasmodium sporozoite surface protein-2 atau disebut juga TRAP (thrombospondin-related adhesive protein). Protein yang berperan sebagai reseptor pada permukaan eritrosit antara lain glikoforin dan antigen Duffy. ${ }^{15}$

Protein lain yang ikut terlibat dalam pembentukan junction ini adalah RON-2 (Rhoptry neck protein). RON-2 yang dihasilkan oleh rhoptry akan masuk ke dalam membran eritrosit dan akan membentuk ikatan dengan AMA-1 (Apical Membrane Antigen-1) sehingga membentuk komplek RON-2 - AMA-1. ${ }^{17}$

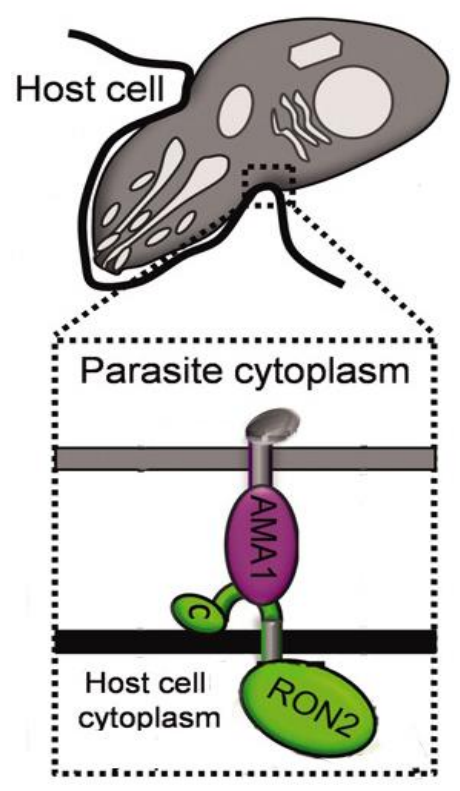

Gambar 6. Peranan rhoptry dalam pembentukan junction ${ }^{17}$

Junction tersebut dapat bergerak karena adanya aktifitas aktin - miosin, an- 
tigen permukaan yang mengalami translokasi dari apical end menuju posterior end sehingga biasa sering disebut sebagai moving junction. ${ }^{15}$

\section{d. Merozoit masuk ke dalam eritrosit}

Pada saat terbentuknya junction, terjadi redistribusi protein membran eritrosit sehingga area kontak merozoit - eritrosit bebas dari protein membran eritrosit. Peristiwa ini diikuti oleh pembentukan parasitophorous vacuolar membrane (PVM). Komponen pembentuk membran ini terbentuk dari protein host dan protein parasit. Pergerakan merozoit menginvasi eritrosit terjadi karena aktifitas aktin-miosin dan protein TRAP (thrombospondinrelated adhesive protein). Protein micronema ini, selain berperan sebagai ligand dalam pembentukan ikatan merozoiteritrosit juga berperan dalam invasi dan gliding motility. Pada saat junction mencapai apical end, junction akan membentuk cincin dan akhirnya membran eritrosit akan menutup secara spontan. ${ }^{15}$

\section{SIMPULAN}

Infeksi parasit malaria pada tubuh manusia terjadi akibat gigitan nyamuk Anopheles betina yang mengandung sporozoit Plasmodium. Perjalanan parasit ini dari awal infeksi sampai menimbulkan gejala klinis terdiri atas tiga tahap; yaitu tahap pre-eritrositik, tahap intrahepatik dan tahap eritrositik. Pada tahap pre-eritrosit, parasit beredar di sirkulasi untuk seterusnya menginvasi sel hepar. Protein yang berperan dalam proses invasi sel hepar ini adalah SPECT-1 (Sporozoite microneme protein essential for cell traversal-1), SPECT-2 (Plasmodium perforin - like protein PPLP-1) dan fosfolipase. Tahap intra- hepatik dimulai ketika sporozoit berhasil memasuki sel hepar dengan bantuan sel Kupffer. Di dalam sel hepar, parasit membentuk skizon yang terdiri dari ribuan merozoit. Setelah keluar dari sel hepar, merozoit akan menginvasi eritrosit melalui tahap kontak awal, reorienttasi, pembentukan junction dan masuk ke dalam eritrosit.

\section{DAFTAR RUJUKAN}

1. Harijanto PN. Gejala klinik malaria. Dalam Harijanto PN, penyunting. Malaria epidemiologi, patogenesis, manifestasi klinis dan penanganan. Jakarta; EGC 1999.

2. Gandahusada, S. Parasit Malaria. Parasitologi Kedokteran. Jakarta; FKUI 2003.

3. Wykes M, Good MFA. What really happens to dendritic cells during malaria? Nat Rev Microbiol 2008;6:864-70.

4. Silvie O, Mota MM, Matuschewski K, Prudencio M. Interactions of the malaria parasite and its mammalian host. Curr Opin Microbiol 2008;11:352-9.

5. Garcia EJ, Puentes A, Patarroyo EM. Developmental biology of sporozoite-host interactions in Plasmodium falciparum malaria: implications for vaccine design. Clin Microbiol Rev 2006;19(4):686-707.

6. Prudencio M, Rodriguez A, Mota MM. The silent path to thousands of merozoites: the Plasmodium liver stage. Nat Rev Microbiol 2006;4:849-56.

7. Kakkilaya SB. Malaria site. All about malaria. Diunduh dari www.malariasite.com. 2011

8. Good FM, Doolan LD. Malaria vaccine design: immunological considerations. Immunity 2010;33(4):555-66.

9. Baum J, Richard D, Heale J, et al. A conserved molecular motor drives cell invasion and gliding motility across malaria life cycle stages and other apicomplexan parasites. J Biol Chem 2006;281: 5197-208.

10. Good MF, Doolan DL. Malaria's journey through the lymph node. Nat Med 2007;13:1023-4. 
11. Singh AP, Buscaglia CA, Wang $Q$, et al. Plasmodium circumsporozoite protein promotes the development of the liver stages of the parasite. Cell 2007;131:492504.

12. Vaughan AM, Aly AS, Kappe SH. Malaria parasite pre-erythrocytic stage infection: gliding and hiding. Cell Host Microbe 2008;4(3): 209-18.

13. Cowman AF, Crabb BS. Invasion of red blood cells by malaria parasites. Cell 2006;124:755-66.

14. Greenwood BM, Fidock DA, Kyle DE, et al. Malaria: progress, perils, and prospects for eradication. J Clin Invest 2008;118:126676.

15. Wiser FM. Cellular and molecular biologi of Plasmodium. Tulane University. 2013.

16. Holder AA, Blackman MJ, Borre $M$, et al. Malaria parasites and erythrocyte invasion. Biochem Soc Trans 1994;22(2):291-5.

17. Tonkin ML, Roques $\mathrm{M}$, Lamarque $\mathrm{MH}$, et al. Host cell invasion by apicomplexan parasites: insights from the co-structure of AMA1 with a RON2 Peptide. Science. 2011; 333:463-7. 